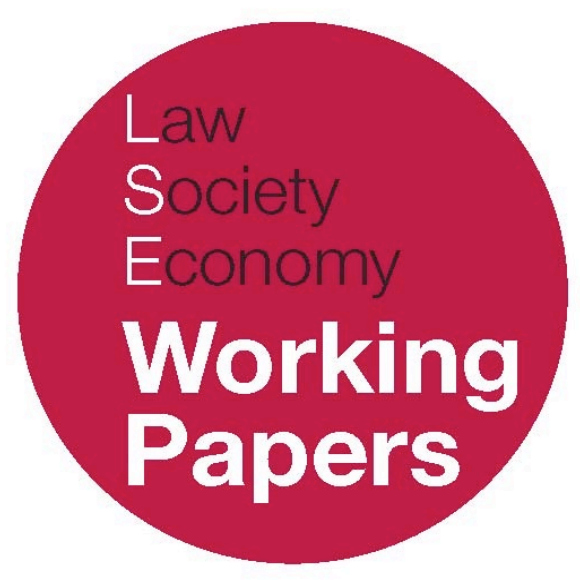

\title{
The protest provisions of the Police, Crime, Sentencing and Court Bill: A "modest reset of the scales"?
}

\author{
Richard Martin \\ LSE Law, Society and Economy Working Papers 15/2021 \\ London School of Economics and Political Science \\ Law School
}

\begin{abstract}
This paper can be downloaded without charge from LSE Law, Society and Economy Working Papers at: www.lse.ac.uk/collections/law/wps/wps.htm and the Social Sciences Research Network electronic library at: https://ssrn.com/abstract $=3973201$.

(C) Richard Martin. Users may download and/or print one copy to facilitate their private study or for non-commercial research. Users may not engage in further distribution of this material or use it for any profit-making activities or any other form of commercial gain.
\end{abstract}




\title{
The protest provisions of the Police, Crime, Sentencing and Court Bill: A "modest reset of the scales"?
}

\author{
Richard Martin*
}

\begin{abstract}
The proposals contained in Clauses 54 to 60 of the Police, Crime, Sentencing and Court Bill seek to expand police powers to restrict non-violent but disruptive or 'noisy' protests. The purpose of this article is to cast a critical eye over the five main proposals with the intention of furthering the discussion and scrutiny of these significant amendments to the Public Order Act 1986. Taking each proposal in turn, the article examines their purported justifications, the clarity and coherence of the provisions and their likely compliance with the European Convention on Human Rights. It concludes the proposals amount to a marked broadening and deepening of protest powers, signalling a desire for a more interventionist, less tolerant police response to non-violent but disruptive protests.
\end{abstract}

\footnotetext{
* Assistant Professor, Law School, London School of Economics and Political Science. A shorter version of this
} working paper can be found in the Criminal Law Review, 12, 2021, pp1008-1028. 


\section{INTRODUCTION}

The provisions in Part 3 of the Police, Crime, Sentencing and Court Bill (PCSC), which concern the policing of protests, have proven highly controversial. This is entirely as it should be. To seek to legislate on the legitimate scope of protest activities in a democratic society worthy of its name ought to excite debate and scrutiny. The proposals contained in Clauses 54 to 60 of the PCSC seek to expand police powers to restrict non-violent but disruptive protests by amendments to the Public Order Act 1986 (POA), as well as the Police Reform and Social Responsibility Act 2011. The Home Office and Her Majesty's Inspectorate of Constabulary and Fire \& Rescue (HMICFRS) have promoted the amendments as part of a "modest reset" 1 of police powers in favour of the rights of the wider community and "a modest updating of legislation that is more than 35 years old". 2 But high-profile responses to Part 3 of the PCSC paint an altogether different picture of the proposals which, if successful, will principally affect police powers to impose conditions on public gatherings and the associated offences in the POA. The proposals have been variously described as "significantly widening police powers on public order", 3 "drastically limiting the right to protest", "threatening to neuter protests in ways that would render them ineffective", 5 granting "expansive powers" which raise "legitimate concerns that it would allow the Government to prevent protests with which it does not agree" 6 and risk an "increase [in] restrictions on non-violent protest in a way that is inconsistent with our rights." 7

The purpose of this article is to cast a critical eye over the five main proposals with the intention of furthering the discussion and scrutiny of these significant amendments. Taking each of the proposals in turn, the article examines their purported justifications, the clarity and coherency of the provisions and their likely compliance with the European Convention on Human Rights (ECHR). This issue of Convention compliance is granted special attention. The law governing protest activities has witnessed a "constitutional shift" over the last two decades. It has moved away from an approach rooted in residual liberties protected through the principle of legality towards a more clearly delineated and substantive rights-based account, ${ }^{8}$ emergent from the right to peaceful protest which is the amalgam of Articles 10 and 11 of the ECHR. ${ }^{9}$ When combined with the duties of public authorities under Article 6(1) of the Human Rights Act 1998 (HRA), the right to

1 Her Majesty's Inspectorate of Constabulary and Fire \& Rescue, 'Getting the balance right? An inspection of how effectively the police deal with protests', March 2021 (London: HMICFRS), herein 'HMICFRS (2021)'.

2 PCSC Bill Deb 8 June 2021, Victoria Atkins, Col 398.

3 PCSC Bill Deb 8 June 2021, Bambos Charalambous, Col 367.

4 Liberty, 'Briefing on the Police, Crime, Sentencing and Court Bill', March 2021, p2.

5 Good Law Project, 'Police, Crime, Sentencing and Courts Bill 2021 - Briefing for MPs', 15 March 2021.

6 The Bar Council, 'Police, Crime, Sentencing and Courts Bill 2021 Briefing for Committee Stage - Bar Council Summary', p2.

7 Joint Committee on Human Rights, 'Legislative Scrutiny: Police, Crime, Sentencing and Courts Bill, Part 3 (Public Order)', Second Report of Session 2021-22, 16 June 2021 (herein 'JCHR (2021)'), 3.

8 Sedley LJ in Redmond-Bate v Director of Public Prosecutions [1999] 163 JP 789 at 795. See Lord Bingham in R (Laporte) $v$ Chief Constable of Gloucestershire [2006] UKHL 55, and, more generally, D. Mead, The New Law of Peaceful Protest Rights and Regulation in the Human Rights Act Era (Oxford: Hart, 2010) (herein 'Mead (2010)').

9 See Kudrevičius and others v Lithuania [2015] ECHR 906, at \86. 
peaceful protest has significant implications for how any new powers are interpreted by the courts and exercised by police. Having worked through the five major provisions, the article concludes that they amount to a marked broadening and deepening of police protest powers, signalling a desire for a more interventionist, less tolerant police response to nonviolent but disruptive protests. To foreground analysis, let us first begin with a brief account of how and why Part 3 of the PCSC came to be introduced in the first place.

\section{THE GENESIS OF THE REFORMS AND PRE-LEGISLATIVE PROCESS}

The law applicable to the policing of protests is something of a jigsaw puzzle, comprising legislation targeted at managing protest activities directly as well as general public order offences. ${ }^{10} \mathrm{~A}$ detailed survey of the field is not required for our purposes; suffice to say police have considerable powers and criminal offences at their disposal where protestors stray beyond the right to peaceful protest. ${ }^{11}$ It is, though, worth sketching the statutory scheme in sections 12(1) and 14(1) of the Public Order Act 1986 which the PCSC seeks to amend. A senior officer can impose conditions on organizers and participants of a public procession (section 12) or assembly (section 14) where they reasonably believe the gathering may result in serious public disorder, serious damage to property or serious disruption to the life of the community, ${ }^{12}$ or that the purpose of organizers is to intimidate others. ${ }^{13}$ For processions, the type of conditions are open-ended. ${ }^{14}$ For public assemblies, however, conditions are limited to its location, duration and number of participants. ${ }^{15}$ Conditions imposed in advance of a gathering must be by a chief officer and be given in writing. ${ }^{16}$ Where the event is already underway, they can be imposed by the most senior at the scene and need not be given in writing. ${ }^{17}$ The test for the type of conditions imposed is those which 'appear necessary' to prevent potential disorder, damage, disruption or intimidation. ${ }^{18}$ It is a criminal offence to knowingly fail to comply with the conditions contained in a senior officer's direction. Any conditions imposed on an assembly must apply to a particular assembly in a particular location: section 14(1) cannot be used to place conditions on separate gatherings, happening at different times and many miles apart, even if co-ordinated under the umbrella of one body. ${ }^{19}$

The amendments to the POA, discussed in detail shortly, directly impact on the kind of non-violent processions and assemblies which characterize political engagement

10 A brief overview of the relevant law can be found in J. Brown and D. Mead, Police powers: protest, Briefing Paper No. 5013, House of Commons Library, 19 May 2021, 5-9 and, more generally, and P. Thornton, The Law of Public Order and Protest (Oxford: OUP, 2010).

11 For detailed discussion of police powers to manage protest activity, see Mead (2010).

12 s.12(1)(a) and s.14(1)(a), POA 1986.

13 s.12(1)(b) and s.14(1)(b), POA 1986.

14 s.12(1), POA 1986.

15 s.14(1), POA 1986.

16 s.12(3) and s.14(3), POA 1986.

17 s.12(2)(a), s.14(2)(a) and s.14ZA(5)(a), POA 1986.

18 s.12(1) and s.14(1), POA 1986.

19 R (Jones) v Commissioner of the Police for the Metropolis [2019] EWHC 2957. 
and civic participation in democratic societies. This ought to have implications for the nature of the pre-legislative process itself. As observed by Lord Woolf CJ:

"The rights to freedom of expression, and assembly and association, which are protected by Articles 10 and 11 of the ECHR respectively, are of the greatest importance to the proper functioning of any democracy. Any intrusion upon the rights, either by the developing common law or by the intervention of statute law, has to be jealously scrutinised." 20

As the reform process preceding the POA powerfully illustrated, even amidst the heat of inner-city riots and picket-line violence, proposed legislation affecting core democratic rights need not preclude careful review, scrutiny and evaluation of the adequacy of existing law. The crafting of the POA was preceded by a judge-led inquiries, ${ }^{21}$ a Green Paper, ${ }^{22}$ a White Paper, ${ }^{23}$ a Select Committee Report, ${ }^{24}$ and Law Commission report. One might have expected, then, extensive public consultation on the proposed powers, a White Paper setting out the rationale for the reforms or at least a well-timed, inclusive, nationwide review of existing protest powers and offences, including how they have been exercised in the decade since HMIC's major report on public order policing. Regrettably, this has not been the case. ${ }^{25}$

Instead, the genesis for the reforms, right down to the specific amendments sought, arose from in-house discussions between the Home Office, the Metropolitan Police and the National Police Chiefs' Council (NPCC). Although 2020-21 has seen a great many protests on weighty issues of the day, the trigger for the reforms was the Extinction Rebellion (XR) protests in April 2019 in London - readers may recall the 'pink boat protest' - during which the Metropolitan Police made over 1,000 arrests for breaches of section 14 of the POA. That month, the then Home Secretary, Sajid Javid, expressed his concern to the Metropolitan Police about the disruption caused by protests. This prompted communication and collaboration between the Metropolitan Police and NPCC about perceived gaps in the POA and what might be done to plug them. ${ }^{26}$ This culminated in a roundtable involving the Home Office, NPCC, College of Policing, police forces, police lawyers and HS2 in June 2019 to explore "the most practical legislative options that would assist in policing protests more effectively." 27 Just one month later, in July 2019, a total of 19 potential changes to the law were put forward by the Metropolitan Police on behalf of the NPCC, four of which found favour with the Home Office and now find

20 R (Laporte) v Chief Constable of Gloucestershire Constabulary [2004] EWCA Civ 1639, at [35].

21 The Red Lion Sq. disorders of 15th June 1974; Report of an Inquiry by the Rt. Hon L.J. Scarman (Cmnd. 5919, 1975); Report of an inquiry by Rt. Hon. Lord Scarman - The Brixton Disorders (Cmnd. 8427, 1981).

22 Review of the Public Order Act 1936 and related legislation (Cmnd. 7891, 1980).

23 Review of Public Order Law (Cmnd. 9510, 1985).

24 House of Commons Select Committee on Home Affairs - The Law Relating to Public Order, 5th Report (197980 H.C. 756).

25 Her Majesty's Inspectorate of Constabulary, Adapting to Protest - Nurturing the British Model of Policing (London, 2009).

26 HMICFRS (2021), 108.

27 HMICFRS (2021), 108. 
form in Part 3 of the PCSC.28 The extent to which these proposals are based on an objective, evidence-based evaluation of police use of their existing powers across England and Wales might well depend on one's view of HMICFRS's review and the timing of it.

In September 2020, the Home Secretary commissioned HMICFRS to review how effectively police manage protests, the adequacy of existing powers and the merits of the legislative proposals. The review was conducted during the second wave of the pandemic, a most challenging and in-opportune time to inspect police forces and engage with stakeholders. With respect, though, the review did little to re-calibrate a police-dominated appraisal of the proper scope of their powers to interfere with, and criminalize, non-violent protest. Only four protest organizations had input into HMICFRS's report, in contrast to the 22 police forces and 15 police-related organizations involved. Based on HMICFRS inspection of 10 forces, stakeholder feedback and an online public survey, its general conclusion was that police do not accurately assess the level of disruption protestors may cause and too readily favour the rights of protestors on occasion, something out-of-sync with public opinion towards disruptive protests. Expressed through the slippery metaphor of balancing, HMICFRS considered a "modest reset of the scales" was required. ${ }^{29}$ Put plainly, the report's suggestion seemed to be that the police ought to be more willing to interfere with the peaceful protest because of the serious disruption that protests do, in fact, cause if only police were to look harder for signs of disruption. HMICFRS offered qualified endorsement of the legislative proposals on the basis they would "improve police effectiveness". 30 This was accompanied by a health warning that any new powers would have to be exercised in a manner compliant with human rights law.

Before moving on, though, two findings from the HMICFRS report ought to give pause for reflection on the need for reform in the first place. First, the existing panoply of police protest powers were rarely used at all in recent years. Very few conditions were placed on protests, arrests for breach of conditions were seldom, and where prosecutions were brought, almost all resulted in conditional discharge. ${ }^{31}$ In rare instances of section 12(1) and 14(1) being used, it was by the Metropolitan Police, most notably in response to the 2019 protests. Indeed, the Metropolitan Police readily availed of section 14 to manage the XR protests, making 2,303 arrests for breach of conditions and achieving convictions in roughly 78 percent of cases. ${ }^{32}$ Given the breadth of the existing powers, might this not be evidence of their use in accordance with the kind of facilitative, negotiated style of protest policing recommended by HMIC back in 2009, coupled with a willingness to use powers where serious disruption does arise? Second, the police appetite for legislative reform nationwide seems far from settled. ${ }^{33}$ There were "strikingly different" views reported to HMICFRS on the need for greater powers. Forces experiencing more disruptive protests unsurprisingly favoured more powers, but many officers reported

28 The sheer breadth of the proposed powers and criminal offences envisioned was remarkable. See HMICFRS (2021), pp131-41.

29 HMICFRS (2021), p10, 95

30 HMICFRS (2021), p110.

31 HMICFRS (2021), pp104-6.

32 HMICFRS (2021), p105.

33 In so far as they can be gleaned from the report; the precise breakdown of responses is not given, with reference made to "many" and "some" officers or forces. 
seeing no need for change. ${ }^{34}$ According to the author of HMICFRS' report "Senior police officers outside London-again, I am generalising — tended to think they had sufficient powers, and senior police officers inside London tended to think that more would be useful." "35 If anything, the consistent message seemed to be the need for more resources, not powers, to manage disruptive protests. ${ }^{36}$ Police Scotland was especially frank in expressing concern, if not outright disapproval, towards some proposals because they were not rights compliant, risked an adverse impact on police legitimacy or were simply unnecessary. ${ }^{37}$

In any event, remarkably little time was devoted to digest or debate HMICFRS' report. By the time it was released on 11 March 2021 the PCSC had already been published and had its First Reading two days earlier, by which point justification for the amendments had crystalized around several key claims articulated by the Home Office. The first was an apparent change in protest tactics, namely sits ins, lock-ons and multiple simultaneous assemblies, predominantly in London. ${ }^{38}$ Those familiar with protests throughout the twentieth century, of course, might question just how new such tactics really are, just as they might point to long-standing statutory powers to counter such tactics. The second was the claim that protests are causing "disproportionate amounts of disruption" on the "hardworking majority seeking to go about their everyday lives". ${ }^{39}$ XR emerges as the bête noire of the reforms, described as "hiding behind the guise of protest while committing criminal acts" and imposing a "drain on public funds" because of the costs associated with policing its demonstrations. ${ }^{40}$ The third, and related, is that the POA is "outdated" and "no longer fit for managing many of the types of protests we experience today." 41 What specifically is outdated or how the clauses bring it up to date remains hard to discern. Vague reference has been made to the role of social media in enabling protests to be organized at very short notice, making it harder for police to liaise with those organizing it. 42

\section{(1) The Expansion Of Conditions Capable Of Being Imposed On Public ASSEMBLIES}

Clause 55(2)(c) of the PCSC seeks to amend section 14 of the POA to remove the limit on the types of conditions police can place on public assemblies. This amendment would enable the senior officer to impose any conditions as appear to be necessary to prevent the kind of disorder, damage, disruption, impact or intimidation specified in section 14(1). This amendment was lobbied for by the Metropolitan Police and supported

\footnotetext{
34 HMICFRS (2021), p109.

35 PCSC Bill Deb 18 May 2021, Matt Parr, Col 53.

36 HMICFRS (2021), p97.

37 HMICFRS (2021), p118.

38 Home Office Policy Paper, 'Police, Crime, Sentencing and Courts Bill 2021: protest powers factsheet', 13 May 2021 (herein 'Home Office (2021)') p6; PCSC Bill Deb 8 June 2021, Victoria Atkins, Col 383.

39 Ibid.

40 HC Deb, 7 September 2020, Kit Malthouse, Vol 678, Col 385.

41 Home Office (2021), p1.

42 PCSC Bill Deb 8 June 2021, Victoria Atkins, Col 385.
} 
by HMICFRS. The suggestion of the Home Office, HMICFRS and some senior police was that protests and assemblies have changed since the enactment of the POA, becoming "more fluid", such that it can be hard for commanders to distinguish when a procession becomes a static assembly and vice versa. Practically, the amendment will allow police to impose a wider range of restrictions on static protests, including start and finish times, as well as noise levels, ${ }^{43}$ and conditions on what is chanted, worn and carried by participants. As the NPCC lead for public order policing remarked, the police can now wrap conditions "on the whole of that protest, whether it walks or stands still." 44

This amendment has been justified on the grounds that consistency in conditions capable of being imposed on public processions and assemblies will bring clarity to the law for police and protestors. One might wonder, though, why an effort was not made to address the circularity of the current statutory definition of "procession", or given the operational concerns, work with the NPCC and College of Policing to provide guidance on features indictive of each type of gathering. A "public procession" is defined in section 16 of the POA as a "a procession in a public place". The limited judicial discussion of the term has understood it to mean more than "a mere body of persons; it is a body of persons moving along a route" 45 and the "act of a body of persons marching along in orderly succession." 46 The distinction between an assembly and a procession has not been the subject of judicial determination thus far. Mead has questioned, however, whether definitional ambiguity, such as whether a group slowly shuffling in circles might amount to the "movement along a route", is sufficiently precise and foreseeable to satisfy the 'prescribed by law' requirement in Articles 10 and 11 of the ECHR. 47

A further justification is that the "practical challenge of safely policing" a procession and assembly a protest said to be equivalent, warranting the full panoply of conditions to be available for the latter too. Although framed as a pragmatic response to disruptive assemblies, the amendment fails to engage with the principled basis for limiting the conditions police could place on public assemblies in the first place. The Home Office White Paper, published in 1985 prior to the POA, recognized that there was "major disorder associated static demonstrations" and that "meetings and static demonstrations may just as frequently be the occasion of public disorder as marches." 48 But despite this, the Home Office was wary that any further conditions on assemblies (e.g., date and time) risked being tantamount to a ban and was, more generally, "very concerned not to extend statutory controls over static demonstrations any further than is strictly necessary. Meetings and assemblies are a more important means of exercising freedom of speech than are marches." 49 The elevated status of assemblies is further reflected in the fact that, provided they are not trespassory, they cannot be prohibited, as is the case with

\footnotetext{
43 Home Office (2021), p2.

44 PCSC Bill Deb 18 May 2021, Chief Constable Harrington, Col 12.

45 Flockhart v Robinson [1950] 2 KB 498 (Div Ct) 502.

46 Kent v Commissioner of Police for the Metropolis, The times, 15 May 1981.

47 Mead (2010), pp65, 172.

48 Home Office, 'Review of Public Order Law', May 1985, Cmnd 9510, para 5.1, p31.

49 Home Office, 'Review of Public Order Law', May 1985, Cmnd 9510, para 5.3, p31-2.

9510, para 5.3, pp31-2. Mead (2010) has questioned why this might be so, suggesting the answer may lie in "our historical attachment to mass rallies, and their perceived epoch-changing capability", 169.
} 
processions. Even if gatherings today do shift more easily between assemblies and processions than when the POA was first enacted, the Home Office ought to explain why, as a matter of principle, further restrictions enforced by the criminal law have become necessary, not least given the risks associated with static assemblies were already present in the minds of Parliament when enacting the POA.

Turning to the possible exercise of the amended section 14(1), an especially important issue going forward will be how attractive it will prove to be to police given a marked preference for police to base pre-emptive action on the common law power to prevent an imminent breach of peace from occurring. ${ }^{50} \mathrm{~A}$ breach of the peace arises "whenever harm is actually done or is likely to be done to a person or in his presence to his property or a person is in fear of being so harmed through an assault, affray, a riot, unlawful assembly or other disturbance." 51 The formulation of the power (and duty) of a constable to respond to a breach of the peace was authoritatively re-stated in (R) Laporte:

"Every constable, and also every citizen, enjoys the power and is subject to the duty to seek to prevent, by arrest or other action short of arrest, any breach of the peace occurring in his presence, or any breach of the peace which (having occurred) is likely to be renewed, or any breach of the peace which is about to occur." ${ }^{52}$

An officer may take "reasonable steps" to refrain a person from committing a breach of the peace, including detaining the person against their will, ${ }^{53}$ ordering the person to move on or disperse ${ }^{54}$ or ordering the person not to proceed. ${ }^{55}$ Particularly controversial in the protest context, though, has been the use of breach of the peace to ground the policy of containment, which involves enclosing protests, as well as by-standers, within a police cordon which they may not leave, possibly for long periods of time. ${ }^{56}$

The preference of police to use their breach of the peace powers to control assemblies over the relevant sections of the POA is readily apparent. It avoids the seeming detail and complexity of the POA and, despite the reining in of the breach of the peace doctrine in (R) Laporte through the test of imminence, it remains a remarkably broad, discretionary power with "extensive flexibility built in". ${ }^{57}$ The formulation of the doctrine

50 H. Fenwick, 'Marginalising human rights: breach of the peace, "kettling", the Human Rights Act and public protest' (2009) PL, Oct, 737 (herein 'Fenwick (2009)') and R. Glover, 'Keeping the peace and preventive justice - a new test for breach of the peace?' (2018) PL, Jul, 444.

51 Howell [1982] Q.B. 416, per Watkins LJ, at 427.

52 Laporte [2006] UKHL 55, per Lord Bingham at [29] and Lord Brown at [110].

53 Albert v Lavin [1982] AC 546 (HL) 565.

54 Duncan v Jones [1936] 1 KB 218.

55 Moss v McLacblan [1985] IRLR 76. For detailed discussion of the breach of the peace powers in protest contexts see Mead (2010), pp319-61.

56 In Austin, police detained thousands of demonstrators for approximately seven hours in Oxford Circus, including the claimant, Austin, who asked to be released but was refused on the ground that others in the crowd were threatening a breach of the peace. Ultimately, the House of Lords and ECtHR accepted containment in this case did not amount to a violation of Article 5(1), rendering further scrutiny of breach of the peace powers in this context superfluous. See, more recently, R (Hicks) v Commissioner of Police for the Metropolis [2017] UKSC 9, where it was held that Article 51(c) is capable of applying where arrest and detention on the basis of an imminent breach of the peace is taken for preventive purposes followed by early release (a decision subsequently endorsed by the ECtHR in Eiseman Renyard and Others v United Kingdom [2019] ECHR 237).

57 See Mead (2010), 347. 
as set out in Howell enables police to take reasonable steps to apprehend an imminent breach of the peace where behaviour falls short of violence or threats of violence to people; where the harm or damage may be low (there is no threshold test); where there is no specific act identified as unlawful; and where the persons subject to police intervention are innocent third parties who are not themselves the source of the violence or harm that would breach the peace. ${ }^{58}$ So too has breach of the peace been legitimated by the ECtHR in so far as it recognized the power as being sufficiently clear and precise for the purposes of the "prescribed by law" test. ${ }^{99}$ The use of breach of the peace to control protests has, however, attracted sustained criticism from academic commentators. ${ }^{60}$ Fenwick, for example has argued the power is too broad, ill-defined and undermines the statutory scheme such that argument for abolition of the breach of the peace doctrine is overdue. ${ }^{61}$ In controlling public protest, Fenwick argues it is preferable for police to rely on scheme under the POA, including sections 12 and 14, which has the legitimacy of being specifically tailored to the control of marches. ${ }^{62}$ Mead has similarly underscored the policy argument that where the POA is capable of governing a protest, police should not also be able to call upon the common law. ${ }^{63}$

Yet it has been far from clear whether section 14 of the POA, as originally enacted at least, could step-in and provide a legal basis for the pre-emptive tactics justified using breach of the peace powers. In Director of Public Prosecution v Jones, the High Court held that section 14(1) could be used to establish entry and exit points to an assembly, ${ }^{64}$ but its use to contain and disperse participants of an assembly has been cast in doubt. At first instance in Austin, Tugendhat J held that section 14(1) included a power to direct an assembly to disperse along a particular route, to stay in a particular place so long as necessary to effect that dispersal and that such conditions can be imposed as a result of the acts of others. ${ }^{65}$ The Court of Appeal was not persuaded by Tugendhat J's interpretation of section 14 and saw some force instead in the argument that conditions requiring participants to stay in one place and then disperse ran contrary to the intention of section 14(1) which was about the continuation, not cessation, of an assembly. ${ }^{66}$ The Court of Appeal suggested "further consideration and perhaps amendment" of section 14(1) was warranted if it was to be used as a basis to justify containment and dispersal in exceptional circumstances like Austin.67 The amendment of section 14 in Clause 55(2)(c), however, gives cause to question the Court of Appeal's hesitation in Austin about the legality of imposing conditions of regarding the containment and dispersal of assemblies under section 14. It is submitted that the ordinary meaning of section 14 as amended - coupled with the clear intention of the Home Office to expand the conditions which can be placed on static assemblies -

58 Fenwick cited in Mead (2010), 320.

59 Steel v United Kingdom (1998) 28 EHRR 603.

60 R. Stone 'Breach of the Peace: the case for abolition' [2001] 2 Web Journal of Current Legal Issues; Glover above n.46 and Fenwick (2009).

61 Fenwick (2009), 760-61.

62 Fenwick (2009), p759.

63 Mead (2010), p319.

64 Director of Public Prosecutions v Jones [2002] EWHC 110.

65 Austin v The Commissioner of Police of the Metropolis [2007] EWCA Civ 989, at [76].

66 Ibid, at [80]-[82].

67 Ibid, at [74], [84]. 
means that "any conditions" to prevent the specified outcomes includes directions requiring participants to stay in one place, disperse when instructed to do so or maintain their location until a specified end time.

An unintended consequence of the reform, then, might be to re-orient the legal basis for pre-emptive tactics in relation to static assemblies, including containment and dispersal of protestors, from breach of the peace to section 14. Such a shift towards section 14(1) would throw the adequacy of the statutory safeguards into much sharper relief than has hitherto been the case. ${ }^{68}$ The appeal of section 14(1) for police commanders might lie in the latitude it also grants, especially given the tightening of the breach of the peace doctrine by the House of Lords in Laporte: section 14 does require the disorder, damage or disruption anticipated to be "serious" but beyond this, it fails to provide for the minimum safeguards and control of discretion of breach of the peace powers in three respects. Firstly, the nexus between the activity of protest participants and the specified outcome is lower under section 14(1) than breach of the peace. The latter requires the harm or damage is caused or is likely to be caused; it is insufficient that the breach of the peace is anticipated to be a real possibility. ${ }^{69}$ Section 14(1), however, simply requires the senior officer has a reasonable belief the assembly "may" result in the consequences in section 14(1)(a), not that it will result in them, nor even that it is more likely than not that it will. ${ }^{70}$ Secondly, there is no requirement of "imminence" of the consequences in section 14(1)(a) before conditions are placed on assemblies; the senior officer need only have a reasonable belief the consequences may occur, ${ }^{71}$ and that the conditions "appear to be necessary", a subjective test. ${ }^{72}$ The test of "imminence" was, it is worth recalling, recognition that pre-emptive action taken against peaceful protests "needs the fullest justification"73 and provided a "long-standing safeguard against unnecessary and in appropriate interventions by the police". ${ }^{74}$ Furthermore, where a breach of the peace is reasonably judged to be imminent, police must still take no more intrusive action than appears necessary to prevent $i t:{ }^{75}$ any steps taken must be necessary and proportionate. ${ }^{76}$ Thirdly, where breach of the peace is relied on to take preventive action against innocent parties, including those protected by Article 11, it seems a strict necessity test applies - that is to say, there must be no other way of preventing an imminent breach of the peace. ${ }^{77}$ There is no corresponding requirement in section 14 .

68 Concern about the breadth of sections 12 and 14 as an alternative to breach of the peace was raised in the wake of Laporte and Austin by Fenwick (2009).

69 R (Laporte)(FC) v Chief Constable Gloucestershire [2006] UKHL 55, per Lord Bingham, at [47].

70 R (Brehony) v Chief Constable of Greater Manchester [2005] EWHC 640 (Admin), Bean J at [20]).

71 See Bean J in R (Brehony) at [18].

72 Amendment No. 38 to Clause 12 of the Public Order Bill tabled by Lord Hutchinson sought to limit the power to of the senior officer to impose any condition which would reasonably appear to be necessary in all the circumstances but it was defeated on the basis that the requirement the senior officer have "reasonable belief" that one of the specified consequences may result provided sufficient judicial scrutiny.

73 Laporte, Lord Brown.

74 Laporte, Lord Rodger.

75 Laporte, Lord Brown.

76 R (McClure and Moos) v The Commissioner of Police of the Metropolis [2012] EWCA Civ 12, at [35] and [96].

77 Laporte, Lord Mance, at [149] and Lord Rodger, at [84], albeit this is obiter dicta. 
Finally, the subjective test for necessity and the absence of a proportionality standard in section 14(1) sits uneasily with the proportionality assessment the court will conduct when assessing the lawfulness of exercise of the power in section 14(1) for the purposes of section 6(1) of the HRA. Conditions imposed on a peaceful assembly under section 14(1), either in advance of a peaceful assembly or during it, will constitute an interference with Article 11 of the ECHR. As the ECtHR stated in Austin, even if the police tactic of containment does not amount to a breach of liberty under Article 5(1), proper consideration must still be given to the right to peaceful assembly:

"It must be underlined that measures of crowd control should not be used by the national authorities directly or indirectly to stifle or discourage protest, given the fundamental importance of freedom of expression and assembly in all democratic societies." 78

The expansion of section 14(1) without additional safeguards would amount to a missed opportunity to foreground the concept of proportionality. This could be achieved by replacing the subjective test of necessity with the threshold test that any condition must be "necessary and proportionate". Further still, to avoid interfering with the rights of innocent third parties who are not the source of serious disorder or disruption ${ }^{79}-$ in Convention terms, to avoid penalizing those who are not themselves acting reprehensibly - the word 'result' in section 14(1) might be defined to mean a causal link, not one that is just associational, temporal or incidental. ${ }^{80}$ These additions to the amendments would signal the importance of the proportionality assessment to frontline decision-makers and perhaps reduce the likelihood of successful Convention challenges to directions under section 14.

\section{(2) Defining The 'Serious Disruption To The Life Of The Community' TRIGGER}

That a public procession or assembly may result in "serious disruption to the life of the community" is one of the four consequences in sections 12(1) and 14(1) of the POA that the senior officer may rely on to impose conditions gatherings. As originally enacted, the substance of this strikingly open-textured concept was provided for by the values and ideals of the police commander applying it in an operational context. As one future Prime Minister remarked during passage of the Public Order Bill, "there are as many views as there are policemen as to what constitutes serious disruption to the life of the community." 81 The amendments in Clauses 54(4) and 55(6) of the PCSC mark a significant change to the statutory scheme by permitting the Home Secretary to define any expression in the formulation of the 'serious disruption to the life of the community' trigger and even give examples of cases where an event has or has not satisfied it. The PCSC's attempt to

78 Austin and Others v United Kingdom [2012] 55 EHRR 14, at \68.

79 ECtHR case law on "reprehensible acts" - see later.

80 On this point, and the possible interpretation that might be given to 'result' by domestic courts under section 3(1) of the HRA, see Mead (2010), 206.

81 HC Deb 16 May 1985, Gordon Brown, Vol 79 Col 517. 
clarify a test which, as it stands, is so dependent on subjective values of police, is to be welcomed. Far less clear, though, is why, as a matter of principle, it is the Home Secretary who is bestowed with the principal role in providing its normative content.

To accept this definitional work as belonging to the Home Secretary rather than Parliament because it concerns public order is to view what is at stake through too narrow a lens of crowd control, instead of a broader one of civic participation, expression and assembly. A legitimate concern is that Clauses 54(4) and 55(6) risk amplifying what Mead has described as the trigger's already "oppressive 'them and us' flavour that is counterintuitively at odds with human rights discourse and values." 82 That is to say, there is sense in which the test overlooks the idea that disruption caused by protests might, in fact, have long been and continue to be a vital part of the life of the community in a democratic society. As Laws LJ famously remarked, rights worth having are, after all, unruly things, liable to be inconvenient and tiresome. ${ }^{83}$ The ECtHR has stated particular regard that must be had to pluralism, tolerance and broadmindedness in its application of the proportionality assessment of restrictions on peaceful assemblies:

"Although individual interests must on occasion be subordinated to those of a group, democracy does not simply mean that the views of a majority must always prevail: a balance must be achieved which ensures the fair and proper treatment of minorities and avoids any abuse of a dominant position." 84

Granting the Home Secretary the power to define "serious disruption" risks reactive responses to unpopular demonstrations, causes and campaigns. Indeed, the Home Office Minister told the JCHR that the "flexibility of secondary legislation... means that powers can be updated to mirror changes in protest tactics." 85 As Theresa May herself acknowledged when speaking to these clauses of the PCSC, "[i]t is tempting [for the] Home Secretary to think that giving powers to the Home Secretary is very reasonable, because we all think we are reasonable, but future Home Secretaries may not be so reasonable." 86 The term ought to be defined by Parliament alone, following cross-party deliberation over what degree of disruption a vibrant and healthy democracy ought to tolerate.

The amendments contained in clauses 54(4) and 55(6) also give rise to a fresh tension about the very nature of "the life of the community" that is central to this trigger. Is this referring to a notional or imagined community, with an a priori set of norms, as viewed through the eyes of the Home Secretary? Or is it a real community, made up of residents, businesses, organizations and campaigners etc, an eclectic mix, with views and attitudes of disruption that can only be known when local police engage in situ with the communities they police? The proposed changes to the POA gesture towards the former conception of the community and yet it is the latter which, quite properly, has taken hold

82 Mead (2010), p186.

83 Tabernacle v Secretary of State for Defence (2009) EWCA Civ 23, Laws LJ, at [43].

84 Chassagnou and Others v. France [1999] 29 EHRR 615, at $₫ 112$.

85 JCHR (2021), 23.

86 HC Deb 15 March 2021, Vol 691 Col 372. 
in recent decades - indeed, it is the trajectory heavily promoted as part of a model of negotiated management of protests which seeks to facilitate peaceful protest while being sensitive to local policing concerns. ${ }^{87}$ The College of Policing's Authorized Professional Practice (APP) expects commanders to complete community impact assessments to "assess changes in community feeling before, during and after an incident or event" and "evaluate the impact of protests on those who live in, work in or visit an area". ${ }^{8}$ The status and influence of such assessments becomes less clear, even diminished, by enabling the Home Secretary to give examples of what he or she thinks a community views serious disruption to be.

Turning now to the matter of compliance with the ECHR, the "serious disruption" trigger itself, and regulations crafted by the Home Secretary interpreting it, are not necessarily incompatible with the right to peaceful assembly. The trigger might, for instance, be defined to capture behaviour that falls within the legitimate aims of "public disorder" or "the protection of the rights and freedoms of others" recognized in Articles 10(2) and 11(2) of the ECHR. ${ }^{89}$ Especially significant in considering a public law challenge to any regulation enacted by the Home Secretary is the discretionary nature of the power in sections 12(1) and 14(1): ultimately, the decision to impose conditions, and the choice of conditions, belongs to the senior officer. In determining whether a regulation is incompatible with the Convention, the court will ask whether the provision is "incapable of being operated in a proportionate way and so was inherently unjustified in all or nearly all cases." $" 90$ An $a b$ ante challenge to the validity of legislation on the basis of a lack of proportionality faces a high hurdle. ${ }^{91}$ It is not inevitable that conditions used on the basis of the "serious disruption" trigger as defined by the Home Secretary, even if defined down to include lower levels of disruption, would be disproportionate. The issue of Convention compliance turns, then, on how police impose conditions in a way that is proportionate to the legitimate aim the trigger seeks to promote. Looking ahead, should the Home Secretary exercise the power to define the trigger, the potential grounds of public law challenge are likely, instead, to concern two issues arising from the duty on public authorities under section 6(1) of the HRA.

The first is where "serious disruption" trigger is defined by the Home Secretary in pursuit of an aim that is not legitimate per Articles 10 and 11 of the ECHR. No sample regulation has been provided by the Home Office at the time of writing. A cynic might wonder, though, whether the delegated power might be used to achieve through the backdoor a change to the formulation of the "serious disruption" trigger which was mooted by the Home Office, specifically to allow police to impose conditions to prevent

87 See C. Stott et al, 'Advances in Liaison Based Public Order Policing in England: Human Rights and Negotiating the Management of Protest?’ (2013) Policing: A Journal of Policy and Practice 7(2) 212.

88 See HMICFRS (2021), 91.

89 The aim is also likely to be deemed sufficiently important to justify interfering with the fundamental right: examples given by the Home Office Minister include the delay of ambulances reaching an A\&E ward and disruptions to the transport system during rush hour.

90 Lord Hodge SCJ (with whom Lord Hughes SCJ agreed) in R (Bibi) v Secretary of State for the Home Department [2015] UKSC 68, at [69].

91 Christian Institute v Lord Advocate [2016] UKSC 51, per Lady Hale SCJ, at [2] and [60], and Lord Hodge SCJ, at [69]. 
"a significant impact on the community". One gets a flavour of the "impact" the Home Office had in mind in its draft policy instructions:

"a single or cumulative protest that subjects a community to either continual noise, offensive/graphic banners or continual unpleasant messaging that maybe doesn't meet the threshold of 'offensive' but can be very damaging to residents when continually exposed to it.'”2

"this would help the police manage protests such as those outside abortion clinics and schools, fracking protests and protests that impact on the local businesses/community. These types of protests do not currently meet existing thresholds under section 12(1) and 14(1) for imposing conditions, but the psychological effect of such action can be just as harmful."93

Further analysis is of course best left until any such provision is in fact drafted but a regulation in pursuit of protecting against such impact would throw up fresh issues of Convention compliance under Articles 10 and 11 of the ECHR. The ECtHR has made clear Article 11 of the ECHR must be considered in the light of Article 10 where an assembly involves the expression of personal opinions or the need to secure a forum for public debate and the open expression of protest. ${ }^{94}$ Article 10 protects information and ideas that offend, shock or disturb the State or any sector of the population, "such are the demands of that pluralism, tolerance and broadmindedness without which there is no "democratic society." 95 On the face of Articles 10(2) and 11(2), the "protection of morals" may be invoked as a legitimate aim for imposing restrictions on the right to freedom of peaceful assembly. But in the absence of expressions that spread, incite, promote or justify hatred based on intolerance, there is limited scope under Article 10(2) for restrictions on political speech or on debate on matters of public interest. ${ }^{96}$ The latter includes "matters which are capable of giving rise to considerable controversy, which concern an important social issue, or which involve a problem that the public would have an interest in being informed about." ${ }^{97}$ In domestic law, the courts have recognized that in conducting a proportionality assessment "it is appropriate to take into account the general character of the views whose expression the Convention is being invoked to protect. Political views, unlike 'vapid tittle-tattle' are particularly worthy of protection." 98

It is submitted that the Home Secretary would likely face a formidable challenge in convincing a court that conditions imposed because of "unpleasant messaging" or undefined "psychological effects" are in pursuit of a pressing social need or are strictly necessarily - not least given existing public order and harassment offences. As public authorities, it would be unlawful for police to impose or the courts to impose conditions based on provisions of a regulation which were incompatible the Convention. ${ }^{99}$ The POA

92 This was quoted in HMICFRS (2021), p116-7.

93 Ibid.

94 Kudrevicius, at $\int 86$.

95 Handyside v United Kingdom [1976] ECHR 5493/72.

96 Morice v France [2015] ECHR 407, at $₫ 125$.

97 Satakunnan Markekinapörssi Oy and Satamedia Oy v. Finland [2015] [2017] ECHR 607 at \} 1 7 1 .

98 Lord Hamblen SCJ and Lord Stephens SCJ, DPP v Ziegler at [86], referencing in part the judgment of Lord Neuberger in City of London Corpn v Samede [2012] EWCA Civ 160 at para 41.

99 section 6(1) of the HRA. 
as amended does not mandate regulations made to take a particular form, meaning there would be no basis under section 6(2)(a) of the HRA to justify enforcing a regulation in violation of the Convention. In fact, there is nothing unconstitutional for police, if confronted by such a regulation which would result in their acting incompatibility with a Convention right, to disapply that provision of the regulation. ${ }^{100}$ If confronted with an offending provision, the question for the reviewing court would be whether it can read and give effect to the subordinate legislation in a way that is compatible with Articles 10 and 11, as per the obligation in section 3(1) of the HRA. Where the incompatibility cannot be cured, and where statutory scheme can be applied without the offending provision (no issue here, the POA has been applied for 35 years without any elaboration of the triggers in section 12 and 14), the court is free to disregard the regulation, as to give effect to it would be unlawful given the court's duty under section 6(1) of the HRA.101

The second possible ground of public law challenge might also arise under section 6(1) of the HRA, this time directed at the necessity of conditions imposed by police based on the "serious disruption" trigger as defined in a regulation. Given the Home Office's concerns about XR's protest tactics in Spring 2019, such a regulation might give examples of disruptive behaviour such as blocking roads or preventing people getting to and from their place of work. This raises an issue recently addressed by the Grand Chamber and the Supreme Court: what degree of disruptive behaviour is protected by the right to peaceful assembly? In Kudrevicius, the Grand Chamber observed that once a protest reaches a certain level of serious disruption it drifts towards the outer limits of the right to peaceful protest:

"although not an uncommon occurrence in the context of the exercise of freedom of assembly in modern societies, physical conduct purposely obstructing traffic and the ordinary course of life in order to seriously disrupt the activities carried out by others is not at the core of that freedom as protected by Article 11 of the Convention."'102

Where demonstrators attempt to prevent or alter the exercise of an activity carried out by third parties, the court noted the significance of how direct or indirect the disruption caused is to the activity of which protestors disapprove:

"the intentional serious disruption, by demonstrators, to ordinary life and to the activities lawfully carried out by others, to a more significant extent than that caused by the normal exercise of the right of peaceful assembly in a public place, might be considered a "reprehensible act" within the meaning of the Court's case-law." 103

What constitutes the "normal exercise of the right" will turn on the degree of tolerance expected in a democratic society, which cannot be defined in abstract but on the specific circumstances and extent of disruption caused. ${ }^{104}$ In Kudrevicius, prolonged obstructions to the city's main arterial routes were not directly aimed at an activity which the protestors'

100 RR $v$ Secretary of State for Work and Pensions [2019] UKSC 52, at [27].

101 Ibid at [29]-[30].

102 Kudrevicius at $\$ 97$, emphasis added.

103 Kudrevicüus at \$173, emphasis added.

104 Primov and Others v Russia [2014] ECHR 605, at \145; DPP v Zielger, Lord Sales SCJ, at [142]. 
disapproved (the government's alleged in action over the decrease in the prices of agricultural products) but at the physical blocking of another activity of third parties (the use of highways by carriers of goods and private cars) which had no direct connection with the object of the protest.

Crucially, though, the kind of deliberate physically obstructive conduct described in Kudrevicius, should it find its way into a regulation drafted by the Home Secretary, will still enjoy the protection of Article 11 and thus any conditions imposed on protestors who engage, or might engage, will still require justification. This was emphasized recently by the Supreme Court in DPP v Ziegler, which concerned protestors' deliberate obstruction of a highway. ${ }^{105}$ Reviewing the Strasbourg authorities, including two cases brought against the UK which concerned obstructive activities directed at the target of the protests, ${ }^{106}$ the Supreme Court drew attention to the fact that "deliberate obstructive conduct which has a more than de minimis impact on others, still requires careful evaluation in determining proportionality" and "such disruption is not determinative of proportionality". ${ }^{107}$ As the Grand Chamber noted in Kudrevicius, though, a serious level of disruption "might have implications for any assessment of 'necessity"'108 and national authorities "will enjoy a wide margin of appreciation in their assessment of the necessity in taking measures to restrict such conduct." 109 This alludes to the fair balance that must be struck having regard to the rights and freedoms of others affected by such disruption.

\section{(3) The New Power To Impose Conditions Due to Noise}

Many, if not, most protest gatherings and cultural events constituting public processions or assemblies are noisy affairs: shouting, chanting, cheering, clapping, singing, playing music et cetera are part and parcel of conveying ideas, raising awareness of issues, and expressing grievances. The use of what the Home Office describes as "egregious noise not as a method of legitimately expressing themselves, but to antagonise and disrupt others" has been deemed to be a type of mischief in need of address and which police, under current legislation, lack confidence to address. ${ }^{110}$ The PCSC thus amends the POA to extend the senior officer's power to impose conditions by persons taking part in public processions, assemblies or the new category of a 'one-person protest' where the noise generated has the potential to cause either of two specified types of impact. The Home Office has stated the "test for being able to impose conditions on noisy protests "will be appropriately high. Police will only use it in cases where it is deemed necessary and proportionate." 111 As drafted, however, the test is simply a senior officer's subjective belief

105 Director of Public Prosecutions v Ziegler and Others [2021] UKSC 23.

106 Steel $v$ United Kingdom (a protest physically impeding the activities of those participating in a grouse shoot continued to enjoy protection under Article 11) and Hashman and Harrup v United Kingdom (measures taking against a protest which impeded the activities of those which the protestors disapproved were an interference with Article 10).

107 Lord Hamblen SCJ and Lord Stephens SCJ, DPP v Ziegler, at [67].

108 Kudrevicius, at \97.

109 Kudrevičius, at $\$ 155$.

110 PCSC Bill Deb 8 June 2021, Victoria Atkins, Col 386.

111 Home Office (2021). 
in the necessity to impose conditions. Given the controversy surrounding these clauses, it is worth subjecting the two threshold criteria for noise trigger to close scrutiny.

The first is the "organizational activities" test: whether the noise generated by participants "may result in serious disruption to the activities of an organisation which are carried on in the vicinity [of the procession/ assembly/ one-person protest]". ${ }^{112}$ No elaboration of the test is provided for in the PCSC; this is a task, once again, left to the Home Secretary by way of secondary legislation. ${ }^{113}$ In the absence of secondary legislation, notable uncertainties exist, as best illustrated by way of example. What constitutes "an organization"? Presumably it captures businesses but what about embassies, government departments, public authorities or emergency services? Might conditions be imposed where one interferes with the activities of police officers or paramedics, for example in communicating with one another or the members of the public they are trying to interact with or treat? Presumably it includes broadcasting organizations, including activities of journalists and field reporters. Might conditions be imposed on a noisy protest taking place, for example, near a live news broadcast, such as the temporary studios occasionally erected in the vicinity of Parliament? But just how far do "activities" of an organization extend? Might conditions be imposed on a noisy protest taking place in a residential area because it seriously disrupts employees of a business who are working from home? Presumably activities of businesses include selling its products or offering its services. If a noisy protest dissuades customers from entering a department store or clients from using their high-street bank, can corporations expect police to impose conditions? Barclays, for instance, has been repeatedly targeted by environmental activists over its links with fossil fuel companies.

The second is the "nearby persons" test: whether the noise generated by participants "may have a significant relevant impact on persons in the vicinity." 114 This involves a twostage test. First, the impact must be "relevant". This will be satisfied where the noise may result in either intimidation or harassment, 115 or alternatively, serious unease, alarm or distress, ${ }^{116}$ of people of reasonable firmness with the characteristics of persons likely to be in the vicinity. Second, such impact must be significant having regard to the likely number of people of experiencing the relevant impact, the duration of the impact, and the intensity of the impact. ${ }^{117}$ While noise might, in some extreme cases, be sufficient to satisfy the "serious disruption to the life of the community" trigger, the new test is less demanding: it can be used against single protestors or small groups whose noise is not of a high decibel but is potent in its agitation of a specific group of people likely to be nearby. The test is also lower than the one which constitutes the offence in section 5(1) of the POA. The latter requires threatening words or behaviour to actually be used, that they are used within hearing of a person, and the person likely be caused harassment, alarm or distress. Under the "nearby persons" test, conditions can be imposed even where the person is not actually

112 Clauses 54(2)(a), 55(2)(b) and 60 of the PCSC.

113 Ibid.

114 Ibid.

115 Ibid.

116 Ibid.

117 Ibid. 
in the vicinity, the noise may result in the specified consequence and the result is serious unease. ${ }^{118}$

A crucial issue Parliament ought to expressly confront and seek to address in its further scrutiny of the noise trigger is whether 'noise' refers merely to the manner and form of the sound or whether it also extends, far more controversially, to the content of the noise too. The OED definition of noise is a sound that is loud (a question of scale) or unpleasant (arguably a question of content) or that causes disturbance (a question of effect). Given the substance of the "relevant" and "significant" limbs of the noise test, it is possible to read the noise test as concerned not only with sound in the first sense but also the latter sense of the word. Furthermore, there is a lack of clarity concerning which characteristics are relevant for the purposes of judging the possible impact of the noise and what is the benchmark against which this to be assessed. Is it concerned with characteristics which affect the gravity of a relevant impact such as intimidation or harassment (e.g. protected characteristics like race, gender, sexuality), those which would make a person more susceptible to say alarm or distress (e.g. age or psychiatric condition), or simply characteristics which reduce a person's steadfastness or tolerance relevant to feelings of serious unease (e.g. a conservative disposition or acute fear of the climate crisis)? Where noise may result in intimidation or harassment, imposing conditions on the type of language used or proximity of protests to the group of persons affected is likely to be uncontentious. For example, anti-abortion campaigners, positioned outside an abortion clinic shouting abuse at pregnant woman who attend the clinic and might likely be distressed at such sound. ${ }^{119}$

More controversial, though, is where the impact may result in "serious unease" if noise constitutes content as well as its manner and form. As commonly defined, unease is a feeling of anxiety or discontent. Protests are often about challenging the status quo, making people feel uneasy and reflect on their habits and behaviours, but also preconceptions and prejudices. Might the power be exercised to impose conditions on protestors campaigning for racial justice, whose chants calling, say, for the removal of colonial statues or demands for reparations for centuries of colonial exploitation, make certain sub-sections of the community feel seriously uneasy at being confronted with this stance on Britain's colonial legacy? Or imposed to restrict the level, type or content of noise on Pride parades - processions of great energy, fanfare and noise - because it would cause serious discontent to those of holding conservative religious beliefs who might be attending events at a place of worship nearby the parade route? Such questions highlight the ambiguity of the "serious unease" criterion and the need to clarify legitimate characteristics of those in the vicinity. What is clear, however, is that any restrictions imposed on a procession or assembly on the basis that the content of the noise causes serious unease to a group of persons of particular characteristics raises real issues under

118 The Home Office Minister stated "through the introduction of these words, we are trying to be consistent with the approach that has long applied in the Public Order Act." (PCSC Bill Deb 8 June 2021, Victoria Atkins, Col 397). However, "unease" is a new addition to the POA.

119 In such circumstances, though, a Public Spaces Protection Order under section 59 of the Anti-social Behaviour, Crime and Policing Act 2014 might be a more appropriate response - see Alina Dulgheriu and Andrea Orthova v Ealing LBC [2019] EWCA Civ 1490. 
Articles 10(1) and 11(1) of the ECHR. The prima facie incompatibility of the test with the Convention has been discussed in detail by the JCHR and need not be repeated here. ${ }^{120}$ Suffice to say, the noise test seems to stumble at the first hurdles of a proportionality assessment: that imposing conditions to guard against possible feelings of "serious unease" constitutes the protection of the "rights and freedoms of others" (Article 8 of the ECHR) or is in pursuit of "indisputable imperative" outside of the rights enunciated in the Convention. ${ }^{121}$

Finally, the noise trigger can also be used to impose conditions on a new category of protest introduced in Clause 60, the "one-person protest". A single protest is one which is, at one time, carried out by one person in a public place. ${ }^{122}$ Where the one-person protestor is moving, or intends to move from place to place, the senior officer must have regard to the route/proposed route. ${ }^{123}$ The section expressly permits conditions to be placed on the route of the protest, as well as prohibitions on the person entering any public place while protesting. ${ }^{124}$ For a single protest already taking place, the most senior officer at the scene will decide if the threshold is likely to be met. The Home Office anticipates that "any protest which it may be necessary to impose conditions is likely to have an officer present of at least the rank of inspector" but provision does not require the officer imposing conditions to be of a minimum rank - unlike a similar provision in section 4(3) of Public Order (NI) Order 1987, which required a minimum rank of inspector or superintendent depending on the type of event. In the absence of such a requirement and given that no notice of a one-person protest is necessary, the exercise of the power, and any assessment of proportionality undertaken, could well be a constable on patrol, with no requirement for the notice to be given in writing or reasons for the officers' reasonable belief to be given to the one-person protestor in great detail. ${ }^{125}$

\section{(4) The Revised ‘Controlled Space’ Surrounding Parliament}

The freedom of protestors to assemble in Parliament Square and the area surrounding it has been subject to contraction and expansion. The Serious Organised Crime and Police Act 2005 (SOCPA) introduced restrictions and a permission requirement on those wishing to demonstrate within one kilometre of Parliament. The overlyrestrictive and ineffective nature of these provisions led to the removal of these powers and the creation of a more liberal regime, achieved through the Police Reform and Social Responsibility Act 2011 (PRSRA). ${ }^{126}$ The underlying police powers under section 14 of the POA were re-introduced but supplemented with further powers to prohibit specific

\footnotetext{
120 See JCHR (2021), at paras 29-62.

121 See Chassagnou, at $\int 113$.

122 Clause 60 of the PCSC, proposing s. 14(ZA)(4), POA 1986. One might think here of Steve Bray, who made daily protests against Brexit in College Green, Westminster and was regularly heard in the background of TV broadcasts (https://www.standard.co.uk/news/politics/stop-brexit-steve-bray-silenced-protest-policing-billsadiq-khan-b925183.html).

123 Clause 60 of the PCSC, proposing s. 4(ZA)(3)(a), POA 1986.

124 Clause 60 of the PCSC, proposing s.14(ZA)(3)(b), POA 1986.

125 See Bean J in R (Brehony), at [18].

126 Section 141(1) of the PRSRA.
} 
activities within two newly specified "controlled areas" of land: Parliament Square and the Palace of Westminster. ${ }^{127}$ Within these areas the use of "amplified noise equipment" (e.g., loudspeakers and loudhailers), the erecting of tents and the use of 'sleeping equipment' is prohibited. A constable (or other authorised person) who has reasonable grounds for believing that a person is doing, or is about to do, a prohibited activity in the controlled areas may direct the person to cease doing that activity or not to start doing it. Failure to comply with the direction without reasonable excuse is a criminal offence punishable by an unlimited fine. The aim of the PRSRA measures was thus to minimize disruptive activities and ensure general enjoyment of the public space surrounding Parliament.

However, in the last few years increased protest activity in the vicinity of Parliament but also the intimidation and harassment of MPs has raised concerns over safe access to and from Parliament for its Members, journalists, and visitors. In October 2019, the JCHR encouraged "a zero tolerance approach to obstruction and intimidation (as opposed to protest) around Westminster." 128 It recommended introducing a statutory duty on police to protect the UK's democratic institutions and the right of access to the Parliamentary estate for those with business there. ${ }^{129}$ But rather than follow this recommendation, the Home Office instead has introduced Clause 57 of the PCSC which amends the PRSRA by expanding the scope of police powers within the existing "controlled areas" regime. First, it expands the controlled area referred to as the Palace of Westminster, within which the prohibitions on noise and encampments apply, to include a number of surrounding streets and the land immediately adjoining them, specifically Canon Row, Parliament Street, Derby Gate, Parliament Square and part of Victoria Embankment (between Bridge Street and Richmond Terrace). ${ }^{130}$ Second, it prohibits the obstruction of the passage of a vehicle into or out of the Parliamentary Estate, where that entrance or exit is within, or adjoins, the Palace of Westminster controlled area. ${ }^{131}$ The failure to comply with a direction by an officer to stop, or not start, obstructing the passage of a vehicle is an offence.

Obstruction is widely defined as "making the passage of a vehicle more difficult", by the use of any item or otherwise, and applies to a vehicle of any description. ${ }^{132}$ Might this include waving one's placard on the pavement close to the road, or indeed one's mere presence close to an entry or exist the passage, if means the vehicle driver has to pay extra care and attention? This expansion of powers has rightly prompted the JCHR to reiterate the importance of protestors being able to demonstrate outside democratic institutions and have their voices heard; the new powers, if enacted, should thus be used "sparingly and only when necessary". ${ }^{133}$ Finally, the geographical scope of the power to issue a direction prohibiting the obstruction of a vehicle is arguably open to some discussion depending on how one reads the reference in Clause 57(3)(a) to "an entrance into or exit from the Parliamentary Estate". In its strict sense, this might refer to the immediate vicinity

127 As defined in section 142A of the PRSRA.

128 JCHR, 'Democracy, freedom of expression and freedom of association: Threats to MPs', First Report of Session 2019-20, 16 October 2019, at para 76.

$129 \mathrm{Ibid}$, at para 72.

130 Clause $57(2)$ of the PCSC.

131 Clause $57(3)$ (a) of the PCSC.

132 Clauses 57(3)(c) and 57(3)(a) of the PCSC.

133 JCHR (2021), at para 120. 
within which a vehicle crosses the threshold between the Parliamentary Estate and the public street the vehicle is turning off or into. Such an entrance or exist might typically be marked by the presence of a barrier gate, lodge or other form of security. A more liberal interpretation is available if one places emphasis on the specific reference to the entrance or exit from the Parliamentary Estate as one that "is within... the Palace of Westminster controlled area as", such that it might include a vehicle's approach or departure along the streets in the controlled area. On the text of the provision alone, the former, stricter, interpretation is preferable. The use of "entrance" and "exit" in its noun form suggests a fixed place in and of itself. If the latter interpretation was to have been intended one would have expected the use of "entering" or "exiting", or most simply, "the route into or out of an exit or entry", to connote the wider process of a vehicle's arrival or departure at a point.

\section{(5) The New Criminal OfFEnCES}

The PCSC will expand criminal liability by widening the scope of pre-existing offences. The criminal offences in sections 12(4)-(6) and 14(4)-(6) of the POA are parasitic on breach of the conditions placed on public processions and assemblies. The effect of the PCSC's clauses to increase the types of conditions police can impose will affect criminal liability in three ways. First, in the context of public assemblies, a wider range of protest activity will now be criminalized due to the lifting of the limits on conditions police can impose on such gatherings. Second, the proposed noise condition expands criminal liability both by adding a new substantive type of condition, breach of which is an offence, and in expanding the application of this condition to the one-person protestors. Third, in context of controlled areas, it will make it an offence to fail to comply with an officer's direction to stop (or not to start) obstructing of vehicle into or out of the Parliamentary Estate. The expanded offences are coupled with increases in the statutory maximum sentences for some of the main protest related offences contained in the POA. The maximum sentences for failure to comply with conditions contrary to sections 12 and 14 are increased as follows:

- For an organiser: an increase from three months or a fine not exceeding level 4, to six months' and/or a fine not exceeding level 4;

- For a participant: an increase from a fine not exceeding level 3 to a fine not exceeding level 4;

- For person who incites a participant: an increase from three months or a fine not exceeding level 4, to six months' and/or a fine not exceeding level 4.134

These uplifts in potential sentencing severity have been justified by the Home Office on the basis that "increasingly disruptive" and "distressing" tactics used by protestors mean "existing sentences are no longer proportionate to the harm that can be caused." 135 With respect, though, the available sentencing data suggests sentencing judges do not share this 
view of the increased severity in offenders' failure to comply with conditions. In 2019, for example, 93 percent of the cases where the offender was found guilty of breaching of condition imposed on a public assemblies per section 14(1) of the POA resulted in a conditional discharge. ${ }^{136}$

The parasitic nature of criminal liability on breach of conditions on public gatherings which are a core characteristic of democratic societies naturally channels the evaluation of the PCSC's amendments through a human rights paradigm. As important a matter of public law this is no doubt is, it should not be allowed to distract from similarly principled concerns emanating from within the liberal criminal law paradigm itself. The criminal law is not only a regulatory instrument through which to encourage compliance with lawful aims through sanctions but a system of state power, a central function of which is to censure wrongdoing. That is to say, the criminal law is said to have a moral voice which it uses to convey the seriousness of misconduct based on the harm and culpability caused. ${ }^{137}$ The expansion of offences and increase in maximum sentences were, according to the Home Office, necessary to provide "punitive outcomes that reflect the seriousness of offences committed by protesters." 138 There are two features of the PCSC's expansion of criminal liability, however, that sit uncomfortably with liberal criminal law values.

The first concerns the culpability of $\mathrm{D}$ who fails to comply with a police condition imposed under sections 12(1) or 14(1) of the POA. As originally enacted, liability only arose where $\mathrm{D}$ knew a condition on the procession or assembly had been imposed. The PCSC amends this to allow for liability where the person "ought to know" the condition has been imposed. ${ }^{139}$ This change in the mens rea requirement was advocated for by the Metropolitan Police to fill a perceived lacuna where protestors sought to avoid criminal liability by covering their ears or tearing up written direction handed to them by police so as not to have "knowingly" failed to comply with the condition. ${ }^{140}$ Each case is, of course, fact dependent but the examples provided by the Home Office arguably constitute wilful blindness and thus such conduct might be regarded as evidence from which knowledge may be inferred by the tribunal of fact. ${ }^{141}$ If prosecutions are not currently being brought in such circumstances, a prosecutorial guideline to address this would be a more targeted response. The effect of the objective test, according to the Home Office, will be to change the onus on the prosecution "from having to show that an individual was fully aware of conditions, to showing that the police took all reasonable steps to notify them."142 If this is the intention, though, why not expressly provide for it in legislation, as is the case, for example, in section 63 of the Criminal Justice and Public Order Act 1994, which states a police direction that people leave a rave is deemed to be communicated to them "if reasonable steps have been taken to bring it to their attention".

136 Figures quoted in HMICFRS (2021), p106.

137 A. Ashworth. 'Is the criminal law a lost cause?' (2000) LQR, 116, 225.

138 Home Office and Ministry of Justice letter to the Joint Committee on Human Rights, 9 March 2021, 2.

139 This is achieved through Clauses 56(1) and 56(10) of the PCSC which introduce ss $1(\mathrm{aa})$ and $1(\mathrm{ab})$ in ss 12 and 14 of the POA respectively.

140 Home Office (2021); PCSC Bill Deb 8 June 2021, Victoria Atkins, Col 389.

141 See the dicta of James LJ in R $v$ Griffiths (1974) 60 Cr App R 14.

142 PCSC Bill Deb 8 June 2021, Victoria Atkins, Col 391. 
The shortcoming of this provision though is less to do the mischief it seeks to target than it is with the imprecision with which it seeks to do so, with the consequent risk of over-criminalization. Without doubting the earnest efforts of police to inform protestors of conditions - e.g., loud halers, social media, giant screens, flyers etc - the objective test's flaw is that it presumes that taking reasonable steps to inform protests en masse of conditions means an individual protestor ought, therefore, to know of such conditions. The protestor at the back of the crowd who cannot see the screen, who hears only a muffled Tannoy announcement or is not on social media risks criminal liability without any obvious fault on their part. ${ }^{143}$ This seems particularly salient where conditions are imposed during the procession or assembly, amidst the excitement, commotion and noise of the procession or assembly. Furthermore, liability arises in relation to D's knowledge of the condition being imposed, not D's knowledge that their actions constitute $a$ breach of the condition. The JCHR gives the example of where a person attends a gathering limited to 100 people if they knew or ought to know of this limit, even if they had no idea that they were the 101st person to join it. ${ }^{144}$ So too is it relevant to D's culpability that in imposing the condition in the first place, there is no need for the senior officer to form the view protestors have any intent or wish to cause any of the trigger consequences in sections 12(1) and 14(1), still less that they should have criminal intent. ${ }^{145}$

This departure from subjectivism perhaps makes it worth recalling the value that underpins it in in criminal law in the first place. The concept of subjectivism is grounded in a theory of excuses which seeks to guard against punishment being arbitrarily imposed on those who are not at fault for any harm they cause. ${ }^{146}$ As famously articulated by HLA Hart, "In this way the criminal law respects the claims of the individual as such, or at least as a choosing being, and distributes its coercive sanctions in a way that reflects this respect for the individual. This surely is very central in the notion of justice..."147 The proposed amendments to sections 12 and 14 give $\mathrm{D}$ no warning, and thus opportunity, to adjust her conduct to the law's requirements in a way that respects her moral agency. D need not have knowingly defied the law's demand. D cannot be deemed culpable for her wrongful choice where she might be unaware such a choice must even be made. These concerns could, however, be addressed through two amendments put forward by the JCHR. These would (i) replace "ought to know" with intentionally or recklessly avoiding knowledge of the condition imposed and (ii) introduce a requirement the person knows, or ought to know, their action or inaction amounts to a failure to comply with the condition. ${ }^{148} \mathrm{~A}$ further provision would be welcome to clarify that "failure to comply" must allow the person to whom the condition is directed a reasonably practicable opportunity to comprehend and comply with it. ${ }^{149}$

143 For a good example see the facts of $\mathrm{R} v$ Lucas, unreported, 17 April 2014.

144 JCHR (2021), at para 85.

$145 \mathrm{R}$ (Brehony), at [16].

146 For a critical discussion of subjectivism in the context of pre-emptive offences see P. Ramsay, 'Preparation Offences, Security Interests, Political Freedom' in R.A. Duff et al. (eds) The Structures of the Criminal Law (Oxford: OUP, 2011).

147 H.L.A. Hart, Punishment and Responsibility: Essays in the Philosophy of Law (Oxford: OUP, 2009), 49.

148 See JCHR (2021), Annex, p38.

149 See, in this respect, the interpretation of "failure to comply" given by the trial judge, in $R v$ Lucas. 
Even if such amendments are adopted though, the lack of a "reasonable excuse" defence raises potential issues of Convention compatibility where $\mathrm{D}$, charged with an offence under sections 12(1) or 14(1), argues the action which constitutes a failure to comply with the condition is protected by Article 11 and a conviction would amount to a disproportionate interference with the right. 150 As stated by Lady Arden SCJ in Ziegler,

"The Human Rights Act 1998 has had a substantial effect on public order offences and made it important not to approach them with any preconception as to what is or is not lawful." ${ }^{\prime 151}$

As clarified by the majority in Ziegler, a conviction amounts to a distinct interference with Article $11 .{ }^{152}$ It is possible, therefore, for a police decision to impose a condition to be proportionate but the potential conviction for the breach not to be so. ${ }^{153}$ The trial judge must, therefore, conduct their own proportionality assessment of the conviction; the police assessment "cannot be more than a cross-check and it may prove to be a misleading diversion." 154 In the protest context, however, this proportionality assessment has been housed within defences of "reasonable" or "lawful" excuse, ${ }^{155}$ which, consistent with the court's duty under section 3(1) of the HRA, has been construed to mean that where a conviction would amount to an unlawful interference with the Convention, the claimant will have such an excuse. ${ }^{156}$ The issue is that neither sections 12 and 14 have this defence in which to house a proportionality assessment; there is no way of escaping conviction even where the conduct is protected by the right to peaceful assembly. This is a matter Parliament should address so as to avoid the court having to resort to section 4 of the HRA. ${ }^{157}$

The second feature of the amendments which sits uncomfortably with a liberal conception of criminal law concerns the type of harm - "serious unease" - the noise trigger targets. This condition permits liability to ride on the back of conditions imposed on the basis of a risk of harm too poorly defined, remote and indirect. To use Duffs terminology, ${ }^{158}$ the offence is noncommensurate: it does not require the actualisation of the risk, the senior officer's subject belief the consequence "might" result is sufficient; (extremely) indirect. harm would ensue only given further, wrongful actions by the protestor

150 The fact an assembly is unlawful does not necessarily justify interference with freedom of assembly (Oya Ataman v. Turkey [2007] ECHR 493, at \39) and the enforcement of rules governing public assemblies cannot become an end in itself (Primov and Others, at $\ 118$ ). But as surmised by the Supreme Court from the Strasbourg jurisprudence, "whilst there is autonomy to choose the manner and form of a protest an evaluation of proportionality will include the nature and extent of actual and potential breaches of domestic law." (DPP v Ziegler, at [77]).

$151 \mathrm{Ibid}$ at [92].

152 DPP v Ziegler, Lord Hamblen SCJ and Lord Stephens SCJ at [64], with whom Lady Arden SCJ agreed; Lord Sales SCJ, with whom Lord Hodge SCJ agreed, dissented on this point, see [124]-[125].

153 Ibid at [57].

154 Ibid, Lady Arden SCJ, at [94], and Lord Hamblen and Lord Stephens, at para 57.

155 See, for example, section 137(1) of the Highways Act 1980 and Regulation 7 of the Health Protection (Coronavirus, Restrictions) (No. 2) (England) Regulations.

156 DPP v Zielger, R (Dolan) v Secretary of State for Health and Social Care [2020] EWCA Civ 1605.

157 A similar concern arises in relation to the PCSC's codification of the common law offence of public nuisance, which does not, as per the Law Commission's recommendation, include a defence of reasonableness (Simplification of Criminal Law Public Nuisance and Outraging Public Decency' - Law Com No 358, 2015, HC 21).

158 R. A. Duff: "Criminalising Endangerment" in Duff, A. and Green, S., eds, Defining Crimes: Essays on the Special Part of the Criminal Law (Oxford: OUP, 2005), 56-64. 
or others and, further still, there is no requirement that the class of persons that might be harmed is actually in the vicinity at the time of the noise; and (partially) implicit: the definition of the relevant risk the relevant person might be exposed - "serious unease" suffers from a striking lack of clarity. This amendment takes the law further into the realm of what has been described "pre-crime" which "shifts the temporal perspective to anticipate and forestall that which has not yet occurred and may never do so."159 But it also exposes how protest conditions and in turn, criminal liability, are concerned more than ever with setbacks to second-order harms of feeling insecure, joining a series of offences - antisocial behaviour, sex offenders, football hooligans, organized crime, terrorism characterized not only by possible risk but "demands [of] outward attitudinal conformity". ${ }^{160}$ In this case societal norms determined by a Home Secretary who has the power to issue regulations defining the meaning of this contentious trigger.

\section{CONCLUSION: LOOKING AHEAD TO THE POWERS IN ACTION}

The cumulative effect of the clauses in Part 3 of the PCSC amount to more than a "modest" update of police protest powers. In breadth, they will permit restrictions, accompanied by criminal liability, to be placed on non-violent assemblies in a greater range of situations and places, based on lower thresholds and lesser safeguards than currently. In depth, they will allow for more intrusive restrictions to be placed on the right to peaceful protest, disregard the subjective knowledge of the protestor for the purposes of criminal liability and increase the maximum sentence for breach of a condition. The purported justifications for this widening and deepening of the law are unconvincing. When one considers the consistency in tactics of recent protest gatherings with those of the last century, the extremely limited use by police of existing powers in the POA to manage protests and the notable scepticism from police outside the capital about the need for greater powers, one wonders whether these amendments are less about addressing a pressing social need and more about enabling the Government of the day to signal a strong distaste for a series of disruptive protests in London and a desire for a more interventionalist police response.

The amendments to the POA will add significantly to the weight which already rests on the shoulders of public order commanders in determining how to exercise their powers in sections 12 and 14 in a Convention compliant manner. The proposed noise trigger, and the "serious disruption" trigger if defined by the Home Secretary, will invite police to intervene more with the right to peaceful protest. Commanders will have to think especially carefully about the proportionality of conditions in such circumstances. It is of obvious concern, therefore, that HMICFRS found forces do not do enough to share case law on protest policing, that the College of Policing's APP is out of date (including the omission of important cases), and that some forces have an insufficient knowledge of

159 L. Zedner, 'Pre-crime and post-criminology' (2007) Theoretical Criminology, 11(2) 261, 262.

160 Ramsay, above n.149, at 222. 
human rights law. ${ }^{161}$ It is regrettable, though, that the ECtHR's jurisprudence was described by HMICFRS as simply "having a bearing" on how domestic law is interpreted and acting as a "useful point of reference" for police.162 This is an understatement. Domestic courts "must take into account" the ECtHR's judgments. ${ }^{163}$ The Ullah principle, as expressed by Lord Bingham, requires the courts "to keep pace with the Strasbourg jurisprudence as it evolves over time." 164 Greater familiarity with Strasbourg case law ought to help commanders ensure compliance with section 6(1) of the HRA in demanding operational situations. Far from worrying about having to have "human rights textbooks at their elbows", ${ }^{165}$ a working familiarity with the concept of proportionality in particular, and its application to the factual scenarios emerged from the case law, can in fact aid commanders in gauging the degree of disruption police must tolerate in navigating the wide discretion granted to them by the proposed amendments. 166

There is an understandable sense of trepidation about how the new powers might be used to stifle peaceful protest in the future. ${ }^{167}$ One is reminded, though, of the findings of PAJ Waddington's seminal ethnographic study with the Metropolitan Police's public order commanders in the wake of the then newly enacted POA. Its most controversial provisions were barely used at all: no marches had been banned, few restrictions had been placed on protests and arrests were rare in the years after its introduction. ${ }^{168}$ Fast-forward three decades, POA powers continue to be used sparingly: there were over 2,500 protests between 21 January to 21 April 2021, and conditions were imposed no more than a dozen times.169 Waddington found commanders' reluctance to engage with their powers reflected, in part, uncertainty over the precise meaning and application of the POA. One wonders, today, just how attractive the likes of the noise trigger would really be to commanders given the complexity of the test and the ambiguity of its terminology. But more crucially, Waddington highlighted the importance of informal means of managing protests, achieved through negotiations between police and organizers. This was the real site where the exercise of peaceful assembly was won or lost. In these negotiations, the law was of little assistance and rarely mentioned: it risked removing the air of friendliness and co-operation commanders consciously cultivated with protestors. ${ }^{170}$ Legal powers were thus typically reserved for less "institutionalised" groups, such as unruly youths or

161 HMICFRS (2021), 12, 42, 54; PCSC Bill Deb 18 May 2021, Matt Parr Col 53.

162 HMICFRS (2021), 72, 73.

163 section 2(1)(a) of the HRA.

164 Lord Bingham in R (Ullab) v Special Adjudicator [2004] UKHL 26, at [20]. See also the discussion and endorsement of this approach by the Supreme Court in R(AB) v Secretary of State for Justice [2021] UKSC 28, per Lord Reed at [54]-[58].

165 A concern expressed in R (SB) v Governors of Denbigh High School by Lord Hoffmann, at [68].

166 See R. Martin, Policing Human Rights (Oxford: OUP, 2021), Chpt. 6. A public order commander might find the guidance on proportionality in the context of lawful assembly and protest on the highway provided by Lord Neuberger in City of London Corpn at paras 39-41 especially helpful.

167 See the oral evidence given to the JCHR by Kevin Blowe, Jules Carey and Zehrah Hasan, HC 1324, Wednesday 28 April 2021.

168 P.A.J. Waddington, Liberty and Order: Public Order Policing in a Capital City (London: UCL Press, 1994), 37-9. Herein 'Waddington (1994)'.

169 Chief Constable Harrington, oral evidence to the JCHR, HC 1324, Wednesday 28 April 2021.

170 Waddington (1994), 87. 
football hooligans. ${ }^{171}$ If enacted, the impact of the amendments, then, might be more subtle and indirect: first, in further shifting the balance of power in informal negotiations with protest organizers towards police due to a greater range of powers they could use if protestors do not "play the game" and, second, in how the political soundtrack accompanying the PCSC might influence commanders' proportionality assessments.

The soundtrack emanating from the Home Office is one that speaks of the need for a "reset" in how rights of protestors and those of others in going about their everyday business are balanced; for commanders to be less tolerant of disruption to community, with a focus on the impact on businesses; and for the criminalization of protestors who breach police conditions which they "ought to know" are in place. HMICFRS' report has similar tenors too. It marshals public survey data to imply police use of powers are out-ofsync with what the majority view to be acceptable levels of disruption - the anti-thesis of a rights-based approach. It has endorsed most of the PCSC amendments provided "they are applied proportionately and in line with human rights law" - but this comes with an important qualification. According to HMICFRS, police are not striking the "right" balance on every occasion in part because "opportunities to lawfully restrict protests that cause deliberate disruption at the expense of the rights of others may be being missed."172 The implication is that "forces outside London may need to become more willing to use their powers from time to time" and training improved so officers "understand how article 10 and 11 rights can be properly tempered." 173 Just how influential this wider soundtrack will be in shaping how police exercise their existing powers and those amended by the PCSC will require a return to the rich kind of ethnographic research exemplified by Waddington. If the publicly available data on the use of sections 11 to 14 of the POA is not improved, though, it will remain difficult to even detect how the use of the POA might vary by protest type, organizers, police forces etc, as well as how many conditions result in breaches and the conviction rate for breaches which are enforced.

171 Waddington (1994), 4.

172 HMICFRS (2021), 83.

173 HMICFRS (2021), 113. 